\title{
MEDHYA EFFECT OF KUSHMANDAVALEHA IN NEUROPSYCHOLOGICAL DISORDERS IN PAEDIATRIC PATIENTS: A CASE STUDY
}

\author{
Pishte-Deshmukh Aditya Jotiram*1, Samant Anant Prabhakar ${ }^{2}$ \\ 1. Assistant Professor, Rasashastra Dept., \\ 2. Associate Professor, Samhita Sidhhant Dept.
}

Dr. J. J. Magdum Ayurved Medical College, Jaysingpur, Maharashtra, India.

Email ID- adityapishte@gmail.com; Mobile no. 09970663766

*Corresponding Author: Email ID- samant.anant@ rediffmail.com; Mobile no. 09420307337

\begin{abstract}
In paediatric patients, neuropsychological diseases such as cerebral palsy are seen. In such cases, as these are asadhya diseases, only yapan is possible, using rasayana an medhya medications. Ghrit kalpana majorly prescribed in such cases. However, children are reluctant to take sidhha ghrita due to disagreeable taste, texture and smell. Also ghrita kalpanas are comparatively costlier. An attempt was made to find an alternative which acts as medhya rasayana, and would be palatable for paediatric patients and also be costeffective than sidhha ghrit. Kushmanda fruit (Benincasa hispida) exhibits medhya properties, and is sheet, brihan and chetorog hrut. Kushmandavaleha is balya, brihan along with having other benefits of kushmanda. Kushmandavaleha was administered to 3 paediatric patients suffering from cerebral palsy, Duchenne's muscular dystrophy and having psychological symptoms such as krodhadhikya, rodan etc in dose $5 \mathrm{gms}$ twice a day. After 30 days, significant effect was seen on these symptoms. Kushmandavaleha can serve as an effective medhya rasayanaa which is economical and palatable in paediatric

patients suffering from neuropsychological disorders.

KEYWORDS:

kushmandavaleha, Medhya rasayan, palatable, neuropsychological disorders, paediatric patients

\section{INTRODUCTION}

Ayurveda has described three types of managements especially for psychiatric and neuropsychological disorders viz; Daiva Vyapashray Chikitsa (Spiritual Therapy), Sattvavajaya Chikitsa (Ayurvedic Psychotherapy) and Yukti Vyapashraya Chikitsa (Rational use of drugs, diets \& activities) which includes samshodhan in adults by panchakarma therapy and samshamana that is the allevation of doshas by different types of drugs, diets \& activities.

Neurology induced mental disorders are seen even in children. E.g. cerebral palsy etc. For such conditions, many medhya dravyas are described in ayurveda, in the form of ghrita kalpana. However in paediatric patients, administration of such medicines poses a problem due to undesirable taste and texture of ghrita kalpana. Also these medicines are
\end{abstract}


available at a comparatively higher price and hence not afforded by patients with low income. So, there is need for medicine which can exert powerful medhya effect and at the same time would be palatable as well as affordable. The avaleha kalpana is specially recommended in children due to its palatability. Kushmanda (Benincasa hispida family Cucurbitaceae)is described as having medhya effect. Bhavamishra praises it as 'Chetorog hrut'. In Sharangdhar samhita, madhyam khand $8 / 28$, kushmadavaleha is described as having balya and brihan properties. Hence, kushmandavaleha was chosen to evaluate its feasibility as an economical, therapeutically effective as well as palatable medhya rasayana for paediatric patients.

\section{AIM}

To find economical, effective and palatable medhya rasayana for paediatric patients having neuropsychological disorders

\section{OBJECTIVES}

- To prepare kushmandavaleha

- To administer the kushmandavaleha to paediatric patient having neuropsychological disorder

- To assess its effect on psychological and systemic symptoms

\section{MATERIAL AND METHODS}

MATERIAL- The drug Kushmandavaleha and patients were material for this study.

\section{METHODS}

\section{Part 1-Kushmandavaleha preparation}

Kushmandavaleha was prepared as per the reference in Sharangdhar samhita madhyam khand 8/22.

Ripekushmanda phala (Benincasa hispida) was taken. Its skin was peeled off and its seeds were removed. The fruit slices (2400 gm) were boiled in double quantity of water $(4800 \mathrm{ml})$ until half the water $(2400 \mathrm{ml})$ remained. The mixture was filtered and decoction was safely kept aside for further use. The cooked fruit slices were taken in a cotton cloth and squeezed to remove water. The slices were then spread on clean cloth and left under the sun for a few hours. Then the cooked slices were put in a grinder to form smooth pulp. The pulp was sautéed in ghrit (clarified butter) (192 gm) in a pan until it ttained light brown colour.

he earlier prepared decoction $(2400 \mathrm{ml})$ was taken in a large vessel, sugar (2400gm) was added to it. It was heated on a medium flame on gas stove until avaleha like consistency was attained. The sautéed kushmanda pulp was then added and mixed uniformly. The vessel was taken off the gas stove, and prakshep dravyas were added viz. pippali, shunthi, jeerak (48 gm each); dhanyak, tamalpatra, ela, marich, twak (12 gm each). After the avaleha was cooled, honey (96gm) was added as prakshep and mixed uniformly. It was then stored in a clean, dry container. 

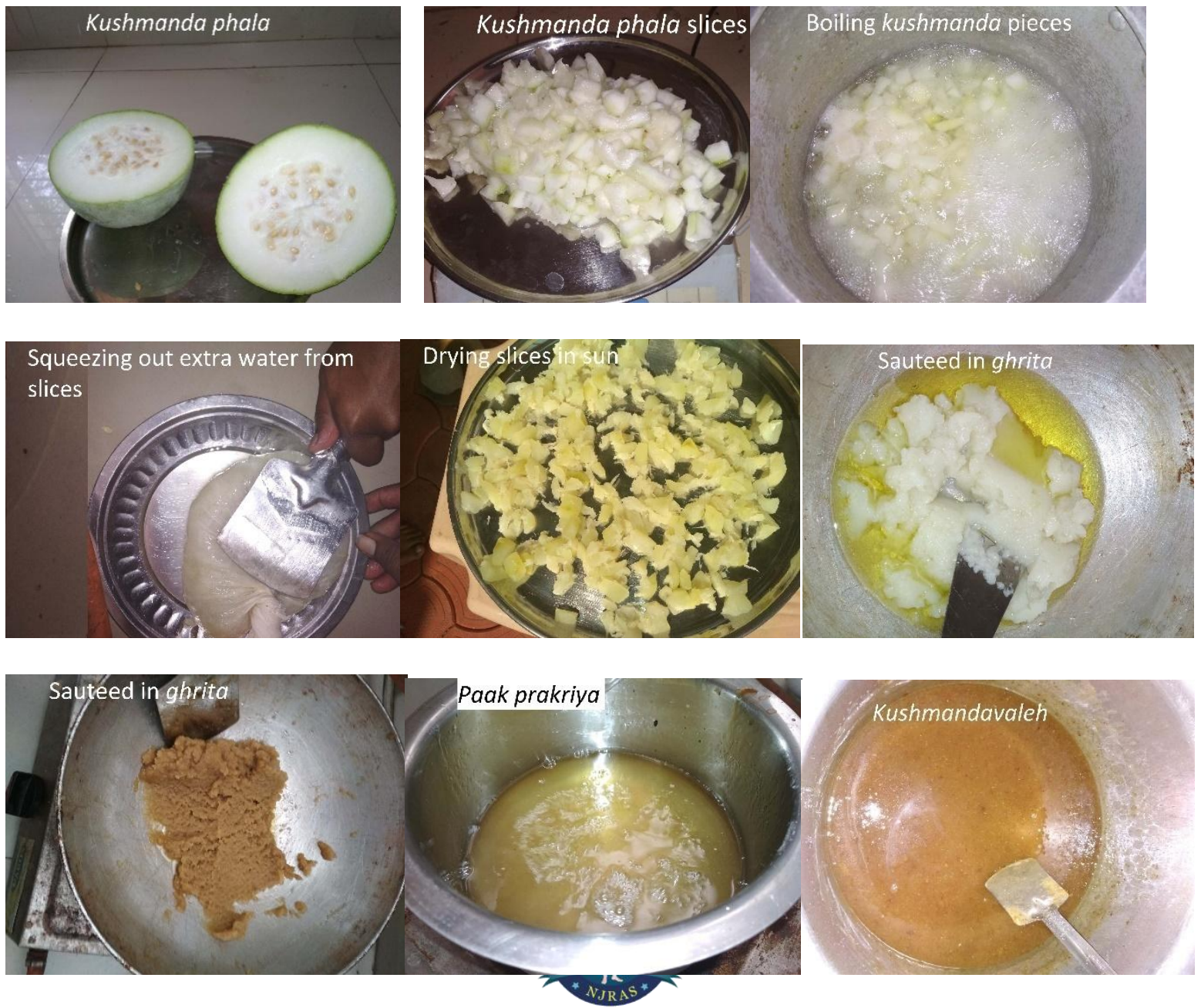

\section{Part 2- Administration to patients}

Patients indicated for trial were selected from out patient and in patient department of Dr. J. J. Magdum Ayurved Hospital, Jaysingpur.

Three patients were randomly selected, based on the psychological manifestations of neurological disorders such as krodhadhikya, chanchalatva, rodan, alpa bhashanam etc. Out of them, two patients were suffering from cerebral palsy while one was suffering from Duchenne's Muscular Dystrophy.

The Kushmandavaleha was administered in dose of $5 \mathrm{gms}$, twice a day, for one month.

\section{RESULTS}

Patient 1

Male, age 5 years, diagnosed with Cerebral Palsy

\begin{tabular}{|l|l|l|l|}
\hline Lakshana & At day 1 & Day 15 & Day 30 \\
\hline Krodhadhikya & ++++ & +++ & + \\
\hline Chanchalatva & +++ & +++ & ++ \\
\hline Ushnasparsha & ++++ & ++ & + \\
\hline Mukhapaak & +++ & + & - \\
\hline Asamyak malashudhhi & +++ & ++ & + \\
\hline
\end{tabular}

Patient 2

Male, age 3 years, diagnosed with Cerebral Palsy 


\begin{tabular}{|l|l|l|l|}
\hline Lakshana & At day 1 & Day 15 & Day 30 \\
\hline Krodhadhikya & +++ & ++ & + \\
\hline Chanchalatva & ++++ & +++ & ++ \\
\hline Ushnasparsha & ++ & ++ & + \\
\hline Mukhapaak & + & + & - \\
\hline Asamyak malashudhhi & ++ & + & - \\
\hline
\end{tabular}

Patient 3

Male, age 6 years, diagnosed with Duchenne Muscular Dystrophy (DMD)

\begin{tabular}{|l|l|l|l|}
\hline Lakshana & At day 1 & Day 15 & Day 30 \\
\hline Krodhadhikya & ++++ & +++ & ++ \\
\hline Chanchalatva & +++ & +++ & ++ \\
\hline Ushnasparsha & ++++ & ++ & + \\
\hline Alpabhashanam & +++ & ++ & + \\
\hline Rodan & +++ & ++ & + \\
\hline Self climbing (Gower's sign) & ++++ & ++++ & +++ \\
\hline
\end{tabular}

\section{DISCUSSION}

Neuropsychological diseases are a serious problem in paediatric patients. Although in allopathic system of medicine very effective anti-psychotic drugs and advanced psychotherapy along with other treatment modalities are available, th outcome is still not very promising. Th diseases like Duchenne's muscular dystrophy, cerebral palsy etc are asadhya as per Ayurvedic view. In such cases, only yapan of the patients is possible. Hence, Rasayana chikitsa proves to be only solution for such diseases. So, attempt is made to find a rasayana, medhya medicine.

The administration to paediatric patients was easier as compared to other kalpas (like bramhi grita) as the medicine was sweet, and having agreeable taste and aroma. On administration to patients, significant effect was seen on parameters like krodhadhikya, chanchalatva etc, as mentioned in the table. Also, in the patient suffering from Duchenne's muscular dystrophy, mamsa pushti was also observed, which is encouraging. In the same patient, alpa bhashanam was earlier seen. After administration of kushmandavaleha, there was gradual improvement in speech and vocabulary.

\section{Probable mechanism of action}

In Bhavaprakash, Shaka varga, Kushmanda fruit is described as having brihan, vrushya, sarvadosh jit and chetorog hrut properties. Chet is taken as a synonym of mana. It denotes that ushmanda can act on psychological symptoms. In all the three patients selected for the study, pitta dosha was observed to be vitiated, and the symptoms were seen accordingly, such as krodhadhikya, mukhapaak, sharir aushnya etc. As per Charaksamhita, Kiyantashirasiya adhyay, in any shirorog, ratka dushti is essentially present. Kushmanda is sheet, also pitta and rakta shamak, and medhya. Thus, it is ideal in such set of lakshanas. The kalpana prepared from it i.e avaleha is snigdha, and also has ghrit in it. The kalpa kushmandavaleha was selected for this study based on its falashruti( balya, brihan, baal vrudhheshu yujyate), rather than its adhikaran (ratkapitta).

Kushmandavaleha acts in neuropsychological disorders due to attributes of medhya, pitta rakta shamak, sheet, balya and brihan.

\section{CONCLUSION}

Kushmandavaleha can serve as an effective medhya rasayana which is economical and palatable in paediatric 
patients suffering from neuropsychological disorders.

\section{REFERENCES}

1. Avaleha, 8th chapter, Madhyam khand, Acharya Shri Sharangdhar, Sharangdhar samhita, New Delhi, Choukhamba publishing house, reprint 2013, page 209

2. Shak Warga, Acharya Bhavamishra, Bhavprakasha nighantu, Varanasi,
Choukhamba Bharati Academy, Reprint 2006, page no. 679

3. Mishra kalpana, Acharya Sidhinandan mishra, Abhinav Bhaishajyakalpana vidnyan, New Delhi, Choukhamba publishing house, reprint 2013.Page no. 173

4. Shlok 11, Kiyantashirasiya Adhyaya17, Sutrasthan, Acharya Charak, Charak Samhita, Varanasi, Choukhamba Bharati Academy 5.

\section{Cite article:}

MEDHYA EFFECT OF KUSHMANDAVALEHA IN NEUROPSYCHOLOGICAL DISORDERS IN PAEDIATRIC PATIENTS: A CASE STUDY

Pishte-Deshmukh Aditya Jotiram, Samant Anant Prabhakar Ayurlog: National Journal of Research in Ayurved Science- 2018; (6)(6):1-5 